\title{
The molecular biology of WHO Grade II gliomas
}

\author{
Nicholas F. Marko, M.D., ${ }^{1}$ and Robert J. Weil, M.D. ${ }^{2}$ \\ ${ }^{1}$ Department of Neurosurgery, The University of Texas MD Anderson Cancer Center, Houston, Texas; \\ and ${ }^{2}$ Brain Tumor and Neuro-Oncology Center, Cleveland Clinic, Cleveland, Ohio
}

The WHO grading scheme for glial neoplasms assigns Grade II to 5 distinct tumors of astrocytic or oligodendroglial lineage: diffuse astrocytoma, oligodendroglioma, oligoastrocytoma, pleomorphic xanthoastrocytoma, and pilomyxoid astrocytoma. Although commonly referred to collectively as among the "low-grade gliomas," these 5 tumors represent molecularly and clinically unique entities. Each is the subject of active basic research aimed at developing a more complete understanding of its molecular biology, and the pace of such research continues to accelerate. Additionally, because managing and predicting the course of these tumors has historically proven challenging, translational research regarding Grade II gliomas continues in the hopes of identifying novel molecular features that can better inform diagnostic, prognostic, and therapeutic strategies. Unfortunately, the basic and translational literature regarding the molecular biology of WHO Grade II gliomas remains nebulous. The authors' goal for this review was to present a comprehensive discussion of current knowledge regarding the molecular characteristics of these 5 WHO Grade II tumors on the chromosomal, genomic, and epigenomic levels. Additionally, they discuss the emerging evidence suggesting molecular differences between adult and pediatric Grade II gliomas. Finally, they present an overview of current strategies for using molecular data to classify low-grade gliomas into clinically relevant categories based on tumor biology.

(http://thejns.org/doi/abs/10.3171/2012.12.FOCUS12283)

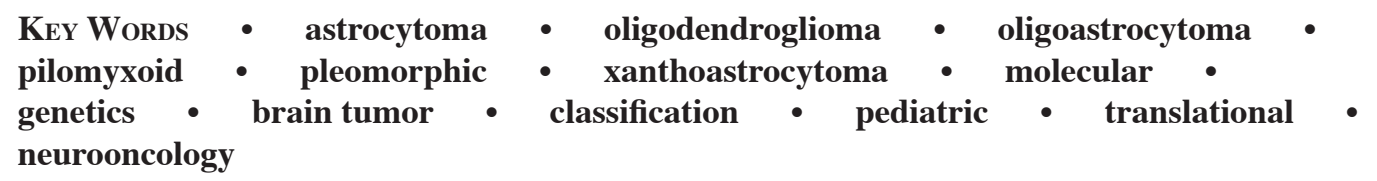

$\mathrm{G}$ RADE II of the WHO grading scheme for glial neoplasms ${ }^{91}$ comprises 5 distinct diagnoses for tumors of astrocytic or oligodendroglial lineage: diffuse astrocytoma, oligodendroglioma, oligoastrocytoma, pleomorphic xanthoastrocytoma, and pilomyxoid astrocytoma. The WHO system classifies solely based upon histological appearance, and so aggregation of these tumors into a single grade reflects their individual, perceived positions along various spectrums of histological aggressiveness rather than any fundamental genotypic or phenotypic similarities. In fact, these 5 tumors represent molecularly and clinically unique entities, and, for this reason, collectivization of these tumors (along with WHO Grade I gliomas) under the heading of "low-grade gliomas" is rapidly falling out of favor. Nonetheless, Grade II tumors differ considerably from WHO Grade

\footnotetext{
Abbreviations used in this paper: $\mathrm{AII}=\mathrm{WHO}$ Grade II astrocytoma; EGFR = epidermal growth factor receptor; IDH = isocitrate dehydrogenase $; \mathrm{LOH}=$ loss of heterozygosity; $\mathrm{OAII}=\mathrm{WHO}$ Grade II oligoastrocytoma; OII = WHO Grade II oligodendroglioma; PDGF $=$ platelet-derived growth factor; PDGFR $=$ PDGF receptor; PXA = pleomorphic xanthoastrocytoma (WHO Grade II).
}

I, III, and IV gliomas, and so the 5 Grade II gliomas are often discussed together.

Managing and predicting the course of these tumors has historically proven challenging, so basic and translational research in Grade II gliomas continues in the hopes of identifying novel molecular features that can better inform diagnostic, prognostic, and therapeutic strategies. Notable success has been achieved in the identification of abnormalities on the short arm of chromosome 1 (1p) and the long arm of chromosome 19 (19q) that have practical implications for clinical management, and this achievement has reinvigorated and rapidly accelerated research into Grade II gliomas.

Despite these successes, the literature regarding the molecular biology of WHO Grade II gliomas remains nebulous. The goal of this review is to present a comprehensive discussion of the current knowledge regarding the molecular characteristics of these tumors on the chromosomal, genomic, and epigenomic levels. We have endeavored to clarify the many points of potential confusion and apparent contradiction that exist within this body of work and to highlight both what is known and what is yet to be 
N. F. Marko and R. J. Weil

investigated. Additionally, we have attempted to organize the data into a logical and organized framework through which it can be more readily understood. A summary of the chromosomal, genomic, and epigenomic changes associated with low-grade gliomas is presented in Table 1.

We have specifically excluded the WHO Grade II tumor of ependymal origin (ependymoma) ${ }^{91}$ from this discussion. Despite technically being a "WHO Grade II glioma," the biology and clinical characteristics of the ependymomas are considerably different from those of the 5 entities that we discuss in this review. We therefore believe that Grade II ependymomas are better treated within the context of a comprehensive discussion of the molecular biology of ependymoma in general. ${ }^{87}$

\section{Diffuse Astrocytoma}

\section{Overview}

The synonymous terms "diffuse astrocytoma" and "low-grade, diffuse astrocytoma" (AII) refer to tumors of astrocytic origin with relatively low proliferative activity and without obvious anaplastic features on histological examination. ${ }^{153}$ The category comprises 3 histological variants, including fibrillary astrocytoma, protoplasmic astrocytoma, and gemistocytic astrocytoma (sometimes described as "variants"). ${ }^{91,134}$ Overall, these tumors represent approximately $1.6 \%$ of all gliomas and $2.1 \%$ of astrocytomas and account for 2,700-4,600 new brain tumor diagnoses per year in the US. ${ }^{153}$ They occur with peak incidence in the young adult population (age 20-34 years), where they represent approximately $10.2 \%$ of primary CNS tumors, $30.0 \%$ of all gliomas, and $25.2 \%$ of all malignant brain tumors. ${ }^{19}$ In this age group their survival rates at 1,5 , and 10 years are $91.6 \%, 58.5 \%$, and $40.7 \%$, respectively. ${ }^{19}$ However, these tumors are observed across all age groups and are associated with relatively longer survival times in the pediatric population and with relatively shorter survival times in older adults. ${ }^{19}$

In the adult population, most AIIs will ultimately progress to anaplastic astrocytomas and then to "secondary" glioblastomas. ${ }^{13,64,91}$ This tendency suggests that AIIs represent an early stage in the evolution of secondary glioblastoma, and many of the molecular characteristics described in AIIs are likely to be early steps along the path to full-scale malignant transformation of the astrocyte. For this reason it is difficult to describe a set of genomic and epigenomic features that are unique to this grade of glioma, and descriptions of the molecular biology of AIIs should be viewed through this lens.

Many molecular investigations include a small number of AIIs as one part of a larger experimental sample containing various grades of glioma. These studies tend to identify genomic and epigenomic changes that occur with relatively low frequency in AIIs and become more prevalent as gliomas progress to higher grades. Reporting the relative frequency of such changes in AIIs adds little to a focused discussion of AII-specific molecular biology, and interested readers should refer to any of a number of texts on high-grade gliomas that place these findings in the context of the molecular pathogenesis and evolution of glioblastoma. ${ }^{8,133}$ Instead, in this section we summarize

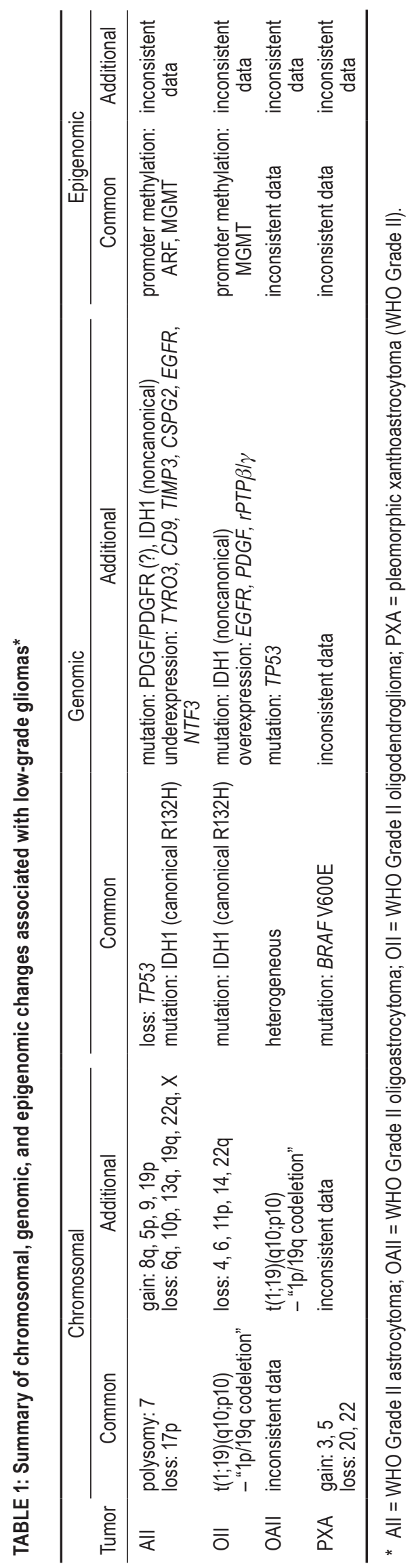

Neurosurg Focus / Volume 34 / February 2013 
those molecular features that appear common to a large proportion of AIIs. These molecular features may logically be assumed to represent at least some of the functionally significant, early subcellular changes involved in the process of malignant astrocytic transformation, and understanding these features may be the most clinically relevant approach to interpreting the molecular biology of AIIs.

\section{Chromosomal Abnormalities}

The most common chromosomal abnormalities in AII are trisomies or polysomies of chromosome 7, ${ }^{91,134}$ with gains of 7 or $7 q$ observed in approximately $50 \%$ of these tumors. ${ }^{158,193}$ Gains in $8 \mathrm{q}$ have also been reported to occur with some consistency in AIIs, ${ }^{116}$ and gains of 5p, 9, and 19p have also been inconsistently observed. ${ }^{133,134,180}$ Chromosomal losses in AIIs have been reported most commonly involving $17 \mathrm{p}^{116,133,185}$ and less frequently on $6 q,{ }^{106} 10 p, 13 q, 19 q, 22 q$, and the sex chromosomes. ${ }^{133,134,177}$

\section{Genomic Abnormalities}

TP53. The TP53 gene localizes to $17 \mathrm{p} 13.1$, and its protein product ( $\mathrm{p} 53)$ is involved in several cellular processes, including cell cycle regulation, response of cells to DNA damage, cell differentiation, and cell death. ${ }^{15}$ Activated p53 induces transcription of p21 Waf1/Cip1, which regulates cell cycle progression at $\mathrm{G}_{1}$ via its activity on cyclin-CDK complexes. ${ }^{15,16}$ The activity of p53 is modulated by MDM4 (MDMX) as well as by MDM2, the latter being modulated ${ }^{118}$ by p14 ${ }^{\mathrm{ARF}}$.

Sixty $(60 \%)$ to $80 \%$ of AIIs have allelic loss on $17 \mathrm{p}$ that includes the TP53 locus, ${ }^{133,1877,185}$ and most AIIs with the retained locus exhibit TP53 mutations. ${ }^{60,66,132,133}$ This makes complete absence of wild-type p53 the most common genomic abnormality in AIIs. ${ }^{133,177}$ The incidence of TP53 mutations is higher in secondary than in primary glioblastoma ${ }^{117,119}$ but does not increase appreciably between AIIs and glioblastoma, ${ }^{160,178,186,187}$ lending genomelevel support to the hypothesis that AIIs represent an early stage in the evolution of secondary glioblastoma..$^{91,118,153}$ This hypothesis is further supported by the findings that common TP53 mutations both in AIIs ${ }^{127}$ and in secondary glioblastomas ${ }^{117}$ occur at codons 248 or 273 (while the TP53 mutations observed in primary glioblastomas are more broadly distributed) and that $\mathrm{G}: \mathrm{C} \rightarrow \mathrm{A}: \mathrm{T}$ mutation in $\mathrm{CpG}$ islands are more frequent in secondary than in primary glioblastoma. The latter observation suggests that different mechanisms may lead to the acquisitions of the TP53 mutations seen in these 2 glioblastoma subtypes. ${ }^{117,133}$

Isocitrate Dehydrogenase. The enzyme isocitrate dehydrogenase (IDH) catalyzes the oxidative decarboxylation of isocitrate to $\alpha$-ketoglutarate in the citric acid cycle and uses NADP ${ }^{+}$as a proton acceptor. ${ }^{34}$ A total of 5 IDH isozymes have been described, although IDH1 and IDH2 are currently believed to be the most relevant to glioma biology. The IDH1 enzyme localizes to the cytosol and peroxisome, ${ }^{34}$ while the IDH2 enzyme assumes the more classic, mitochondrial localization (http://www.ncbi.nlm. nih.gov/gene/3418). A genome-wide analysis of glioblastoma identified IDH1 (2q33) 115 (http://www.ncbi.nlm.nih. gov/gene/3418) gene mutations in $12 \%$ of these tumors, ${ }^{125}$ prompting additional investigations into the potential role of $I D H$ mutation in glioma biology. Subsequent studies demonstrated that IDH mutations are most common in WHO Grade II and III gliomas, as well as in secondary (but not primary) glioblastomas. ${ }^{61,199}$ Approximately $80 \%$ of AIIs have been shown to harbor IDHI gene mutations, and $I D H 2(15 q 26.1)$ gene mutations are often present in the residual fraction. ${ }^{199}$ This finding makes $I D H$ gene mutations the most common and consistent genetic abnormality in AIIs reported to date. Notably, there does not appear to be a statistical association between IDH mutations and TP53 mutations in AIIs, ${ }^{6}$ although these data remain inconsistent. ${ }^{118,190}$

The specific IDH1 mutation observed in low-grade gliomas is almost always ( $>90 \%)^{39}$ a point mutation at position 132, where wild-type arginine is replaced by histidine in the mutant form $(\mathrm{R} 132 \mathrm{H}){ }^{6}$ This mutation is commonly referred to as the canonical IDH1 mutation. Other, rare mutations at this position include substitutions of arginine with cysteine (R132C), serine (R132S), leucine (R132 L), glycine (R132G), or valine (R132 V), ${ }^{6,199}$ all of which can be described as noncanonical IDH1 mutations. These mutations are all heterozygous, and no truncation or frame shift mutants have yet been described. ${ }^{206}$ Position 132 belongs to an evolutionarily conserved region representing the binding site of the isocitrate substrate, ${ }^{6}$ and the R132 mutations result in reduced enzymatic activity toward isocitrate. ${ }^{61,199,207}$ Recent kinetic studies have demonstrated that R132 mutations alter the relative affinity of the IDH1 active site, favoring $\alpha$-ketoglutarate over isocitrate and resulting in increased production of $\alpha$-hydroxyglutarate in cells harboring the mutation. ${ }^{128}$ Structural investigations have suggested a mechanistic explanation for this observation related to its effects on subunit dimerization, ${ }^{200}$ and a "dominant inhibition" model, whereby concurrent underproduction of $\alpha$-ketoglutarate and overproduction of $\alpha$-hydroxyglutarate may favor oncogenesis, has been proposed. ${ }^{206}$ Supplementary hypotheses include contributions to oncogenesis through induction of the HIF- $\alpha$ pathway, ${ }^{207}$ while others suggest that IDH mutations may not be oncogenic but may instead represent protective mechanisms that interfere with the metabolism of tumor cells. ${ }^{209}$

IDH2 is the only human protein homolog of IDH1 that uses $\mathrm{NDAP}^{+}$as a proton acceptor, ${ }^{199}$ and its arginine at position 172 (R172) is exactly analogous to R132 in IDH1. Five point mutations have been identified in IDH2, resulting in replacements of R172 with glycine (R172G), methionine (R172 M), lysine (R172 K), serine (R172S), and tyrosine (R172Y). ${ }^{84,104,199}$ Kinetic and structural studies of IDH2 have not been as extensive as those for IDH1, but the strong similarities between these isozymes and the involved mutations suggest comparable underlying biology.

$P D G F R$. The platelet-derived growth factor receptor (PDGFR) is a tyrosine kinase receptor that interacts with the RAS pathway (and thus the PI3K/PTEN/AKT/ mTOR pathway) ${ }^{118}$ via the SOS-Grb2 intermediary. ${ }^{155,195}$ 
As downstream pathways also modulated by the epidermal growth factor receptor (EGFR), PDGFR-associated pathways have been of considerable interest in glioma research. ${ }^{118}$ This has the potential to lead to some degree of confusion regarding the relative importance of these pathways in AII versus glioblastoma, and it is therefore important to clarify the current molecular evidence regarding PDGFR pathways in AIIs.

A number of preclinical and translational studies have reported putative roles for various components of the PDGF/PDGFR proteins in the biology of glioblastoma. ${ }^{24,90,118}$ However, despite being described throughout the glioma genomics literature ${ }^{91,118}$ as being overexpressed in up to $60 \%$ of AIIs, ${ }^{91,177}$ firm evidence for PDGFR overexpression in AII is sparse. Two small studies from the early $1990 \mathrm{~s},{ }^{41,47}$ each including only 5 AIIs in their analyses, reported that PDGFR- $\alpha$ appeared overexpressed in gliomas of all grades, including AIIs. Attempts to validate this finding have been inconsistent, ${ }^{55,175}$ and ascribing an important, functional role to PDGFR- $\alpha$ in AII on the basis of current evidence appears premature. This distinction is even more important given numerous reports suggesting a role for the overlapping EGFR/RAS/PI3K/PTEN/AKT/ mTOR pathway in the biology of primary but not secondary glioblastoma ${ }^{118}$ and the possible mutual exclusivity between p53 mutations and EGFR overexpression. ${ }^{187}$ Moreover, EGFR overexpression is currently considered to be one factor that distinguishes primary from secondary glioblastoma, as it is observed in approximately $40 \%$ of the former but is rare in the latter. ${ }^{28,88,117,118,187}$ Given these data, it appears that the tyrosine kinase receptor pathways may be of much greater significance to primary glioblastoma biology than to the biology that defines the AII-secondary glioblastoma spectrum.

Other Genomic Abnormalities. A comprehensive meta-analysis ${ }^{143}$ of studies specifically reporting on gene expression in low-grade gliomas performed through 2006 identified only 11 studies $^{37,43,55,56,58,77,89,139,148,174,197}$ describing specific patterns of gene expression in Grade I and/ or Grade II gliomas. The investigators summarized these results, then verified the most commonly reported gene expression patterns using real-time reverse-transcriptase polymerase chain reaction. ${ }^{143}$ With regard to gene expression in AIIs, the authors reported data from 6 studies $^{37,55,56,89,139,148}$ comparing expression in AIIs versus normal controls. They found consistent evidence for underexpression of the TYRO3 gene and for overexpression of the genes CD9, TIMP3, CSPG2, EGFR, PDGFRA, and NTF3 as well as a single report of overexpression of $K C N N 3 .^{143}$ Comparison between AIIs and glioblastoma revealed no instances of specific gene overexpression in AIIs relative to glioblastoma but found consistent evidence for relative underexpression of $N C A M 1, F N, E G F R, V E G F, I G F B P 2$, $I G F B P 3$, and $I G F B P 5$ as well as an isolated report of underexpression of $M M P 16 .{ }^{143}$

In light of the previous comments regarding $P D G F R A$ and EGFR, additional clarification regarding some of these genomic findings ${ }^{143}$ is necessary. Review of the source publications in which PDGFRA and EGFR expression differences were noted ${ }^{55,56,89}$ demonstrates rel- atively small sample numbers, and 2 of the 3 studies $^{55,56}$ were reported by the same research group. One of these studies $^{55}$ reported more than 2 -fold overexpression in PDGFRA to be present in only 2 of 10 AIIs analyzed. Accordingly, we caution against drawing firm conclusions from these data regarding the actual role of $E G F R$ and PDGFRA in AIIs, as considerable evidence (described above) suggests that these genomic features are more consistently associated with higher-grade gliomas.

Additional reports involving AII genomics include those that characterize expression and propose potential roles for human herpesvirus- 6 variants, ${ }^{22}$ the $L G I I^{12}$ and $B R-3^{192}$ gene products, and the SoxD and SoxE gene families ${ }^{156}$ in AII biology and in malignant progression of gliomas. Additional research is necessary before definitive conclusions can be made regarding the putative roles and overall significance of these candidate molecules.

\section{Epigenomic Abnormalities}

Epigenomic investigations represent a relatively recent area of research in the molecular biology of AIIs. The most robust epigenomic data involves the $A R F$ gene, ${ }^{114,188}$ which localizes to the CDKN2A (INK4/ARF) locus on chromosome 9 (9p21). ${ }^{114,159}$ Its gene product, p14 ${ }^{\mathrm{ARF}}$, binds to MDM2 and stabilizes both MDM2 and p53.73,114,159,165 Accordingly, methylation of the $p 14^{A R F}$ promoter results in decreased production of the p14 gene product and relative destabilization of MDM2 and p53. In a single study, $A R F$ (p14 ${ }^{\mathrm{ARF}}$ ) promoter hypermethylation has been documented in $26 \%$ of AIIs, which was frequently observed in AIIs without primary p53 mutations. ${ }^{188}$ All AIIs in this study harboring $A R F\left(\mathrm{p} 14^{\mathrm{ARF}}\right)$ promoter methylation ultimately progressed to secondary glioblastomas.

Similarly, promoter hypermethylation of the DNArepair gene $O^{6}$-methylguanine-DNA methyltransferase $(M G M T)$ has also been observed in $63 \%$ of AIIs. ${ }^{188}$ Interestingly, limited data suggest that $M G M T$ hypermethylation is associated with p53 mutation but is mutually exclusive to $A R F$ (p14 ${ }^{\mathrm{ARF}}$ ) gene hypermethylation. ${ }^{17,188}$ Additional reports suggest epigenomic silencing of the PCDH- $\gamma$-All (5q31), ${ }^{181}$ PTEN (10q23.31), ${ }^{194}$ and EMP3 $(19 \mathrm{q} 13)^{83}$ genes in AII, and further investigations are likely to reveal additional instances of epigenomic abnormalities in these tumors. ${ }^{21,202}$

\section{Clinical Correlations}

Few molecular markers have demonstrated prognostic significance in AIIs. The evidence is most comprehensive for the putative relationship between p53 status and clinical outcomes, but even here the results remain unclear. Early investigations demonstrated no apparent relationship between p53 expression levels and overall survival. ${ }^{48}$ The literature presents conflicting evidence regarding a potential relationship between abnormalities in p53 and malignant progression, with data arguing both for $^{65}$ and against ${ }^{186}$ a potential association. Several studies agree, however, that p53 mutation does appear to be associated with an increased likelihood of tumor recurrence. ${ }^{65,127,186}$ One possible explanation for these nebulous findings may be that the relationship between p53 
status and clinical outcomes varies between subtypes of AII. For instance, some investigators have suggested that much of the overall prognostic impact of p53 status may be related to its disproportionate association with the gemistocytic AII subtype. ${ }^{127}$ Another possible explanation may be that specific p53 mutations are associated with unique prognostic profiles. This is exemplified by the apparent correlation between codon 175 TP53 mutation and an increased risk of progression and malignant transformation. ${ }^{127}$

Other genomic and epigenomic changes may also have prognostic implications. IDHI and IDH2 gene mutations have been suggested as markers of more favorable survival phenotypes, ${ }^{84,104,149}$ although many of the studies in which this has been demonstrated do not necessarily separate AIIs from oligodendrogliomas. It therefore remains possible that disproportionate overrepresentation of oligodendroglioma in the experimental samples of these studies influenced the results, and the ultimate generalizability of these potential prognostic biomarkers specifically to AIIs remains to be determined. Overexpression of EGFR ${ }^{88,175}$ (although uncommon in AIIs) and PDGFR $^{175}$ may be associated with shorter survival times in patients with AIIs. Additionally, MGMT promoter methylation has been associated with response to chemotherapy and thus with improved survival in patients with AIIs. ${ }^{30}$

\section{Oligodendroglioma}

\section{Overview}

The synonymous terms "oligodendroglioma" and "low-grade oligodendroglioma" (OII) refer to tumors of oligodendroglial histology with low proliferative activity and without obvious anaplastic features on microscopic examination. ${ }^{153}$ There are no specific histological variants of OII. Among all grades of glioma (excluding glioblastoma), astrocytic histology is 3 times more common than oligodendroglial histology..$^{91,133}$ Oligodendrogliomas occur with peak incidence in the 3 rd to 5 th decades, ${ }^{91,133}$ and the 1,5, and 10-year survival rates for OIIs in adults are $94.2 \%, 79.5 \%$, and $63.6 \%$, respectively. ${ }^{19}$ OIIs are less common in pediatric patients, ${ }^{91}$ but when they do occur in this age group they are associated with better survival rates than those for OIIs in adults. ${ }^{19}$

OIIs have recently become the subject of considerable attention in translational neurooncology research because they represent the first primary brain tumor that can be routinely and consistently stratified by molecular features into two clinically distinct subgroups. OIIs with "deletions" of 1p, with or without deletion of 19q, respond well to chemotherapy and are associated with a relatively longer survival, whereas those in which $1 \mathrm{p}$ is intact, with or without $19 q$, behave more aggressively. ${ }^{91}$ This finding supports the longstanding concerns of many neurooncologists that histological subtypes of glioma may not adequately capture all clinically relevant variability among these tumors ${ }^{95,96}$ and serves as important proof of principle for ongoing investigations for molecular subclassification of gliomas.

\section{Chromosomal Abnormalities}

The most common chromosomal abnormality in OIIs, occurring in approximately $50 \%$ of these tumors (although some report it in more than 80\%), ${ }^{11,70,74,81,121,136,138}$, ${ }^{153,180}$ is a combined "loss" of the short arm of chromosome 1 (1p) and the long arm of chromosome 19 (19q). ${ }^{91,133,138}$ These tumors demonstrate "loss" of one entire copy of these chromosomal arms due to an unbalanced $\mathrm{t}(1 ; 19)$ (q10;p10) translocation, ${ }^{40,67}$ and this finding is commonly (although technically inaccurately) described as, " $1 \mathrm{p} / 19 \mathrm{q}$ codeletion." Conversely, partial deletions of these loci ${ }^{91}$ or isolated loss of $1 \mathrm{p}^{133}$ are rare. Of the 2 chromosomal losses, $1 \mathrm{p}$ has the greater specificity, as $19 \mathrm{q}$ losses have been observed in other histological types and grades of glioma. ${ }^{162}$ Notwithstanding, $1 \mathrm{p} / 19 \mathrm{q}$ codeletion is not completely specific to OIIs, as it has also been occasionally reported in astrocytomas, oligoastrocytomas, ${ }^{133}$ and glioblastomas. ${ }^{54}$ Combined losses of $1 p$ and $19 q$ appear to be mutually exclusive of several other molecular abnormalities commonly associated with gliomas, including $17 \mathrm{p}$ LOH and TP53 mutation..$^{94,109,172,179}$ This suggests that the molecular pathway leading to the $1 \mathrm{p} / 19 \mathrm{q}$ codeleted OII may be distinct from those involved in other forms of glioma pathogenesis. ${ }^{177}$

The exact molecular mechanisms associated with the development of the unique $\mathrm{t}(1 ; 19)(\mathrm{q} 10 ; \mathrm{p} 10)$ translocation in OIIs are not yet fully understood. Recent evidence suggests that the centromeric regions of chromosomes 1 and 19 show a high degree of sequence homology. ${ }^{176}$ This has been hypothesized to result in centromeric colocalization of chromosomes 1 and 19, which might promote centromeric instability and thus favor the translocation. ${ }^{67,176}$ Additional investigations regarding the specifics of this process and the clinical and molecular significance of this finding are ongoing.

Additional chromosomal abnormalities have also been reported in OIIs, although less frequently than $1 p / 19 q$ codeletions. These include deletions involving chromosome 4, chromosome 6, the short arm of chromosome 11 (11p), chromosome 14, and the long arm of chromosome $22(22 q)^{70,136}$ and occasional losses of chromosomes 9 and $10 . .^{91}$ Array-based comparative genomic hybridization has also suggested submegabase deletions associated with OIIs, including 300- to 550-kb regions on $11 \mathrm{q} 13$ and $13 \mathrm{q} 12 .{ }^{145}$ The validity and consistency of these focal deletions remain to be determined.

\section{Genomic Abnormalities}

1p/19q Candidate Genes. Despite consistent and convincing evidence for $1 \mathrm{p} / 19 \mathrm{q}$ deletions in OII, the specific gene(s) whose loss is associated with the unique clinical phenotype of codeleted OIIs (see below) remains unclear. Proposed candidate genes on $1 \mathrm{p}$ include Notch2 (1p13p11), ${ }^{16}$ DIRAS3 (1p31), ${ }^{203}$ CDKN2C (1p32), ${ }^{59}$ RAD54 (1p32), ${ }^{10}$ CITED4 (1p34.2), ${ }^{169}$ CAMTA1 (1p36), ${ }^{7}$ DFFB (1p36), ${ }^{101}$ TP73 (1p36.3), ${ }^{26}$ and SHREWI (1p36.32). ${ }^{100}$ Because $19 \mathrm{q}$ is completely lost in the OII translocation, mapping studies for identification of candidate gene regions on this chromosome have focused on brain tumors of other histological types with partial deletions of 
19q. ${ }^{45,108,144,162,164}$ These studies have suggested a potential role for several genes on the $19 \mathrm{q} 3$ region, ${ }^{108,144,162,164}$ but additional investigations have not demonstrated consistent mutations of these genes. ${ }^{46}$ Epigenomic studies (see below) suggest potential roles for ZNF342 (19q13), ${ }^{52}$ p190RhoGAP (19q13.3), ${ }^{196}$ EMP3 (19q13.3), ${ }^{168}$ and PEG3 (19q13.4) ${ }^{71,170}$ but definitive evidence for any of these candidate genes has yet to be demonstrated. .1,157,177 $^{-11}$

Isocitrate Dehydrogenase. As in AIIs, IDH1 (and/ or IDH2) mutations are common in OIIs ${ }^{6,84,104,118,199}$ and have been observed in more than $80 \%$ of these tumors. ${ }^{199}$ Many of the studies regarding the specific mutations and their functional significance have been conducted on mixed populations of AIIs and OIIs, and thus the IDH1 R132 and the IDH2 R172 mutations are believed to be the relevant abnormalities in both tumor types. Although the high rate of IDH mutations in both AIIs and OIIs initially suggested that these mutations were independent of other molecular features that distinguished these tumor types, 6,84,104,118,199 more recent evidence suggests that there may be a high degree of correlation between IDH mutations and chromosome $1 \mathrm{p} / 19 \mathrm{q}$ codeletions. ${ }^{84}$ Many of these investigations are conducted in populations with a mixture of OIIs and AIIs ${ }^{6,84}$ and do not stratify independently by $1 \mathrm{p} / 19 \mathrm{q}$ status and WHO grade, limiting the ability to study the relationship in detail. One investigation where stratification was performed, however, demonstrated 1p/19q codeletions in $85 \%$ of tumors with IDH mutations, while no tumors with wild-type IDH were found to be $1 p / 19 q$ codeleted. ${ }^{199}$ The pathophysiological significance of this finding remains to be determined.

Other Abnormalities. EGFR amplification has been reported in approximately $50 \%$ of OIIs, although this represents older data from small studies of relatively few tumors. ${ }^{137}$ PDGFA and PDGFB, as well as their receptors (PDGFR- $\alpha$ and PDGFR- $\beta$ ) appear to be overexpressed in a large percentage of OIIs,$^{23}$ making this finding more common among these tumors than in AIIs. More recently, overexpression of $r P T P \beta / \gamma$ has been reported to distinguish OIIs from AIIs. ${ }^{44}$

The role of the OLIG1 and OLIG2 bHLH-family transcription factors in oligodendroglioma identification merits specific mention. Data from murine models suggests that the $O L I G$ gene products are essential regulators of ventral neuroectodermal progenitor cell fate and oligodendrocyte development. .7,93,146,208 $^{\text {This led to initial }}$ enthusiasm that identification of these markers may assist in the diagnosis of oligodendroglioma. ${ }^{92}$ This enthusiasm has since been tempered by the demonstration that the $O L I G$ transcription factors are overexpressed in most neuroectodermal tumors at both the RNA and protein levels. . $^{1,5120,140}$ Accordingly, the diagnostic role of OLIGI and $O L I G 2$ is currently relegated to that of a molecular marker for general neuroectodermal lineage in brain tumors. ${ }^{5,87}$

\section{Epigenomic Abnormalities}

OIIs demonstrate lower levels of MGMT expression than AIIs. ${ }^{153,161}$ Some evidence suggests that up to $60 \%-80 \%$ of OIIs may exhibit hypermethylation of the
MGMT promoter ${ }^{2,27,107}$ (more common than in AIIs) and that this hypermethylation correlates with $1 \mathrm{p} / 19 \mathrm{q}$ loss, ${ }^{27,57}$ while others have not observed these effects. ${ }^{85,189}$ Additional genes that have been found to be hypermethylated in some OIIs include CDKN2A (9p21), CDKN2B (9p21), ARF (9p21), RB1 (13q14), TP73 (1p36.3), DAPK1 (9q34.1), ESR1 (6q25.1), TIMP3 (22q12.3), THBS (15q15), and GSTPl (11q13). ${ }^{2,136}$

\section{Clinical Correlations}

Perhaps the most widely reported molecular finding with a clinical correlation is the relationship between the combined loss of $1 \mathrm{p}$ and $19 \mathrm{q}$ and improvements in survival $^{31,74,82,150,163}$ and response to chemotherapy ${ }^{18,51,63,72}$ and radiotherapy. ${ }^{9}$ Data regarding the prognostic significance of TP53 mutation status and/or LOH at $17 \mathrm{p} 13$ specifically in OIIs is limited, but some evidence suggests that these may be independent, unfavorable predictors of overall and progression-free survival. ${ }^{102,182}$ Gains on the long arm of chromosome 8 (8q) may also be associated with poor outcomes in OIIs, but these data are derived from a relatively small study on a population of oligodendrogliomas of mixed WHO grades. ${ }^{79}$ While other correlations between molecular markers and survival or response-totherapy phenotypes have been reported, ${ }^{136,177}$ these have almost always been studied primarily in OIIIs, making their generalizability specifically to OIIs unclear.

\section{Oligoastrocytoma}

Oligoastrocytomas (OAII), also called "mixed gliomas,"91 represent a unique WHO class of Grade II glioma that is characterized by tumors exhibiting a mixture of astrocytic and oligodendroglial histological morphology. Molecular evidence suggests that this histological class may comprise an unbalanced mixture of 2 primary tumor genotypes-AII and OII.91,94,136 This is supported by the observation that $30 \%-50 \%$ of OAIIs exhibit chromosome $1 \mathrm{p} / 19 \mathrm{q}$ codeletions ${ }^{81,94,121,138}$ (OII-like), while approximately $30 \%$ carry TP53 gene mutations ${ }^{94,109,121,138}$ (AII-like). Moreover, OAIIs with 1p/19q codeletions have been observed to exhibit more prominent oligodendroglioma-like features on microscopic examination, whereas those with TP53 mutations are more histologically similar to astrocytoma. ${ }^{94}$

One study has proposed that chromosomal data may be useful for subdividing OAIIs into 4 subclasses. ${ }^{69}$ This approach may be reasonable if OAII is a genotypically distinct tumor type but may introduce unnecessary complexity if it is nothing more than a mixture of AII and OII genotypes. This proposed scheme has not been further validated, but it underscores the translational relevance of determining the true genotypic nature of OAII. Without such data only broad correlations of genotype with phenotype are possible for this WHO class, such as in recent investigations suggesting that $1 p / 19 q$ codeletions may be a generally favorable prognostic factor in OAIIs. ${ }^{29}$ While addressing this issue is important, it remains difficult to draw from current data firm conclusions regarding the degree to which OAII biology is novel versus the extent to which the biological observations in OAII can be ex- 
plained simply as a mixture of AII and OII genotypes. One directly related but seldom discussed factor that should be considered when interpreting molecular analyses of OAIIs is the method of extraction of molecular material from the tissue samples. Experimental protocols that homogenize tissue blocks are likely to extract biological samples for analysis that are heterogeneous mixtures of the molecular constituents of both the oligodendroglioma-like and astrocytoma-like tumor regions, while those that use microdissection of specific regions may be more likely to isolate molecular material that is biased toward one of the two constituent cell types. Studies employing the latter methodology are currently lacking, but such investigations are necessary if comprehensive, comparative molecular analyses of the fundamental similarities and differences between tumors classified as OAII, AII, and OII, as well as careful investigations of the clonal origins of OAIIs, are to be performed.

\section{A Comment on Pediatric Grade II Infiltrating Gliomas}

Clinical evidence shows that WHO Grade II infiltrative astrocytomas in pediatric patients have a lower rate of malignant transformation than those in adults $(10 \%$ vs $90 \%){ }^{17}$ These findings suggest that, despite identical WHO classification, pediatric Grade II infiltrative gliomas may represent a unique disease process that could be expected to harbor a novel genotype. Current evidence regarding this hypothesis is nebulous, and it is difficult to draw definitive conclusions regarding the molecular comparability of adult and pediatric Grade II infiltrative gliomas. Although a complete discussion of the molecular differences between adult and pediatric glioma genomics is outside the scope of this review, a brief overview of the current status of these data is beneficial to draw attention to this persistent ambiguity.

Most investigations of specific molecular differences between pediatric and adult low-grade gliomas have thus far been conducted at the chromosomal level. While 50\% or more of adult infiltrating gliomas may have some form of chromosomal abnormality, $11,70,81,121,136,138,158,180,193$ rates for comparable abnormalities in pediatric patients have been reported to be relatively lower. ${ }^{14,105,113,122,123,141,183,198}$ Notwithstanding, chromosomal abnormalities in these pediatric tumors are not rare. ${ }^{105}$ For example, rates of $1 p$ and $19 q$ loss in pediatric populations may be similar to ${ }^{129}$ or greater than ${ }^{112}$ those in adults, although they do not appear to be associated with the same prognostic significance in children. ${ }^{129}$

Definitive conclusions regarding the actual rate of chromosomal abnormalities in pediatric diffuse infiltrating Grade II gliomas, as well as the clinical significance of these findings, are difficult to determine on the basis of current data. Most relevant studies combine (often disproportionately) Grade II gliomas with gliomas of other grades for aggregate analyses of "low-grade gliomas." Aggregation with either pilocytic astrocytomas, in which chromosomal abnormalities are known to be uncommon, or with anaplastic (Grade III) gliomas, in which prognosis may differ, may significantly bias results. ${ }^{14,105,112,113,}$
$122,123,129,141,183,198$ When the primary data are presented in a manner that allows independent examination of infiltrating glioma karyotypes, ${ }^{14,105,113,183}$ the rates of chromosomal abnormalities generally appear higher in the Grade II subgroup than the rates reported for the aggregate data set. This suggests that disproportionate inclusion of pilocytic astrocytomas may artifactually dilute the commonly reported rates of chromosomal abnormalities in pediatric infiltrative low-grade gliomas and that these may, in fact, approach those of the adult population. Similarly, conclusions regarding the prognostic implications of $1 \mathrm{p} / 19 \mathrm{q}$ status in Grade II gliomas may not be generalizable from the population of patients with predominantly Grade III tumors in which it was studied. ${ }^{129}$ Data interpretation is further complicated by the relatively low absolute number of infiltrating gliomas included in many of these studies.

Genomic profiling studies comparing adult and pediatric gliomas suggest that, in general, transcriptome-level differences may exist between these entities, ${ }^{205}$ but data on differential rates of expression of specific genes are currently limited. Some evidence suggests that EGFR overexpression may be relatively more common in pediatric tumors. ${ }^{166}$ Conversely, OLIG 2 expression may be relatively less common. ${ }^{124}$ The clinical significance of these findings remains to be determined.

\section{Pleomorphic Xanthoastrocytoma}

Pleomorphic xanthoastrocytoma (PXA) was first described as a unique histopathological entity in $1979^{76}$ and was characterized in subsequent years as an astrocytic tumor unique in its superficial cortical location, histological variability (pleomorphism), prominent xanthomatous cells, predilection toward occurring in the young, distinct clinical course, and favorable response to surgical resection. ${ }^{32,91,131}$ Literature regarding the molecular biology of PXAs is scarce and incomplete, attributable primarily to the rarity of this lesion. Notwithstanding, a few immunological, cytological, and molecular studies have made significant contributions to the present understanding of PXA as a unique pathological process that is genotypically distinct from other WHO Grade II gliomas.

One distinguishing feature of PXAs, supported by molecular and subcellular findings, is the tendency of these tumors to exhibit a dichotomous astrocytic/neuronal genotype and phenotype. Immunopositivity for glial markers, including glial fibrillary acidic protein (GFAP) and S-100 protein, is consistently present, suggesting a primarily astrocytic phenotype. ${ }^{36,62,130}$ However, neuronal markers, including class-III $\beta$-tubulin, synaptophysin, neurofilament proteins, SMI-31, and MAP2 immunopositivity have also been reported in $8 \%-73 \%$ of PXAs, suggesting neuronal differentiation. ${ }^{36,62,97,130}$ Ultrastructural analyses support this dichotomy, demonstrating features consistent with both astrocytic (intermediate filaments, lipid droplets, lysosomes) and neuronal (microtubules, dense core granules) differentiation. ${ }^{36,49,53}$

PXAs may have diploid or polyploid karyotypes, ${ }^{53,183,184}$ and chromosomal studies have reported gains of chromosomes 3 and 5 and losses of 20 and $22 .{ }^{151}$ DNA loss on chromosome 9 appears to be the most 
common regional chromosomal abnormality in PXA, occurring in $\sim 50 \%$ of these tumors. ${ }^{191}$ Other, less common subtelomeric and regional losses involve chromosome 17 (10\%), as well as 4qter, 6qter, 8p, 9p, 9qter, 10p, chromosome 13, 17pter, 18qter, 21qter, and chromosome 22. ${ }^{38,151,191,201}$ Subtelomeric duplications have been variably reported at 3pter, 8pter, 12pter, 14qter, 16qter, 19pter, and $20 \mathrm{pter}^{38}$ and regional/subtelomeric gains have been documented on chromosome X (16\%), 2p, 4pter, 5, 7, 9q, 11qter, 12, 15q, 19, and 20.38,191,201 Translocations have been described involving chromosome $1,{ }^{86,152}$ and telomeric breakage and fusion events have been reported for chromosomes $1,15,20$, and $22 .{ }^{152}$

Many molecular features that are commonly observed in other WHO Grade II gliomas are generally absent in PXAs. TP53 mutations are uncommon; ;5,75,110,126,204 EGFR overexpression is absent $;{ }^{50} \mathrm{LOH}$ on chromosome 1 , $8 \mathrm{p}, 9 \mathrm{p}, 10,17,19 \mathrm{q}$, and $22 \mathrm{q}$ are only rarely observed; ${ }^{75,126}$ and deletions or epigenomic inactivation involving $C D K N 2 A$ or $C D K N 2 B$ are inconsistent (although potentially functionally significant). ${ }^{75,191}$ Conversely, $B R A F$ mutations (particularly at the V600E "hot spot") are common in PXA, ${ }^{25,111,154}$ a molecular characteristic that they share with pilocytic astrocytomas. ${ }^{25,154}$ PXAs are also unique in their expression of wild-type or truncated CD34, ${ }^{135}$ in their expression of MDM2 without gene amplification,,$^{98}$ and in their immunophenotypic heterogeneity. ${ }^{99}$ Together, these findings suggest that PXAs may share more molecular similarities with pilocytic astrocytomas than with other WHO Grade II gliomas, and several authors have suggested that PXAs represent a pathophysiological entity distinct from other tumors that nonetheless share the same WHO grade..$^{35,38,75,126,173}$

It is also important to note that a small subgroup of PXAs is characterized by more aggressive histological features. These are generally designated as "anaplastic PXA" and assigned to WHO Grade III. ${ }^{11}$ The clinical behavior of these lesions is more aggressive and the prognosis is worse for these lesions than for their WHO Grade II counterparts. ${ }^{4,167,171}$ Because of their rarity, relatively little is known regarding the unique molecular biology of anaplastic PXAs; moreover, a detailed discussion of the molecular biology of these Grade III tumors is outside the scope of this review.

\section{Pilomyxoid Astrocytoma}

Pylomyxoid astrocytomas are WHO Grade II tumors that are closely related to Grade I pilocytic astrocytomas. They are generally hypothalamic/chiasmatic tumors of the very young $(<1$ year old) that may have a more aggressive clinical course than traditional pilocytic astrocytomas. ${ }^{91}$ As a rare tumor and a relatively recent addition to the WHO scheme, few molecular investigations of pilomyxoid astrocytomas have been performed to date. The most comprehensive is a comparison of copy number changes between pilomyxoid and pilocytic astrocytomas. ${ }^{68}$ This study suggested that both tumors share similar chromosomal changes but that pilomyxoid astrocytomas have relatively more regional chromosomal loss on 2 p, 2 q, $3 q$ with additional, occasional differential loss on
$7 \mathrm{p}, 9 \mathrm{q}, 15 \mathrm{q}$, and 20q. ${ }^{68}$ Infrequent differential gains were also noted on $8 \mathrm{q} .{ }^{68}$ Specific genomic differences include a high frequency of underexpression of the ALDHILl gene (89\%), a finding shared with phenotypically aggressive pilocytic astrocytomas that may be of phenotypic significance. ${ }^{142}$ Mutations of $p 53$ may be a feature of pilomyxoid astrocytomas, although these data are based on an analysis of only 3 samples and are therefore difficult to generalize. ${ }^{3}$ A single case of $B C R$ gene disruption occurring in a pilomyxoid astrocytoma ${ }^{103}$ and variable activation of the hedgehog pathway in 4 pilomyxoid astrocytomas ${ }^{147}$ have also been reported.

\section{Molecular Classification of Low-Grade Gliomas}

This review highlights a number of molecular characteristics of low-grade glioma subtypes that may have prognostic and therapeutic relevance. However, because the current WHO system relies solely on histological features for classification, ${ }^{91}$ there is currently no formal mechanism by which molecular data can be used to improve the accuracy of glioma classification. Additionally, ambiguous WHO criteria can make classification of some low-grade gliomas challenging and can introduce subjectivity that may limit the reproducibility of glioma classification. ${ }^{42}$ Accordingly, several investigators have suggested that molecular strategies for glioma classification be considered, and numerous efforts have been made toward developing these strategies for low-grade gliomas.

While a comprehensive review of the topic of molecular classification of low-grade gliomas is outside the scope of this review, an overview of the proposed general approaches to such classification is appropriate. Several proof-of-principle studies have demonstrated the ability to use molecular data to stratify low-grade gliomas into classes that overlap with the WHO scheme. ${ }^{33,95}$ From here, a number of specific strategies have been applied to the task of molecular classification of these tumors. Approaches based on the expression of single genes or gene products have been successful at resolving some of the difficulties associated with purely histological differentiation between AII, OII, and OAII, ${ }^{44}$ and strategies employing various combinations of genomic and chromosomal data have demonstrated similar success in this task..$^{78,109}$ Classification techniques based solely on genomic data for a small subset of genes have also been successfully applied to the task of molecular stratification of various categories of low-grade gliomas, ${ }^{80}$ as have schemes that use more comprehensive sets of gene expression profiles..$^{20,95,197}$ Recently, epigenomic profiles involving patterns of $\mathrm{CpG}$ island methylation have also been used to define subsets of Grade II gliomas with apparent differences in survival phenotype. ${ }^{93}$ The actual methods for classification using molecular data vary from simple algorithms based on one or a few markers ${ }^{44,80,109}$ to more complex mathematical models based on aggregate molecular data sets. ${ }^{33,78,95}$

Issues regarding the practicality of implementation and utilization of molecular classification schemes for low-grade gliomas; the accuracy of putative molecular class discriminators; and the optimal approach for maxi- 
mizing research, diagnostic, and clinical utility of molecular classification strategies are yet to be fully resolved..$^{42}$ Nevertheless, there is considerable optimism in the translational neurooncology community that molecular data will ultimately prove to be a useful adjunct for classification of low-grade gliomas.

\section{Conclusions}

Molecular and translational research in WHO Grade II gliomas remains an area of active research through which several practical discoveries have already been made. Future investigations in this arena will include attempts to clarify the relative importance of potentially clinically relevant molecular markers, including p53, 1p and/or 19q deletion, and IDH1 and IDH2, endeavors to expand upon preclinical discoveries of novel potential markers, and efforts to incorporate molecular markers into tumor classification strategies. We remain optimistic that significant progress toward further understanding of the pathophysiology, the clinical behavior, and the optimal management of these tumors will continue to be made in the coming years.

\section{Disclosure}

Dr. Marco is supported in part by a grant from the American Association of Neurological Surgeons' William P. VanWagenen Fellowship program and by an education and training grant from the Neurosurgery Research and Education Foundation. Dr. Weil is supported in part by the Melvin Burkhardt chair in neurosurgical oncology and by the Karen Colina Wilson research endowment within the Brain Tumor and Neuro-Oncology Center at the Cleveland Clinic Foundation.

Author contributions to the study and manuscript preparation include the following. Conception and design: both authors. Acquisition of data: Marko. Analysis and interpretation of data: both authors. Drafting the article: Marko. Critically revising the article: all authors. Reviewed submitted version of manuscript: both authors. Approved the final version of the manuscript on behalf of both authors: Marko. Statistical analysis: Marko. Administrative/techni$\mathrm{cal} /$ material support: Weil. Study supervision: Weil.

\section{References}

1. Aguirre-Cruz L, Mokhtari K, Hoang-Xuan K, Marie Y, Criniere E, Taillibert S, et al: Analysis of the bHLH transcription factors Olig1 and Olig2 in brain tumors. J Neurooncol 67: 265-271, 2004

2. Alonso ME, Bello MJ, Gonzalez-Gomez P, Arjona D, Lomas J, de Campos JM, et al: Aberrant promoter methylation of multiple genes in oligodendrogliomas and ependymomas. Cancer Genet Cytogenet 144:134-142, 2003

3. Amatya VJ, Akazawa R, Sumimoto Y, Takeshima Y, Inai K: Clinicopathological and immunohistochemical features of three pilomyxoid astrocytomas: comparative study with 11 pilocytic astrocytomas. Pathol Int 59:80-85, 2009

4. Asano K, Miyamoto S, Kubo O, Kikkukawa T, Yagihashi A, Ohkuma H: A case of anaplastic pleomorphic xanthoastrocytoma presenting with tumor bleeding and cerebrospinal fluid dissemination. Brain Tumor Pathol 23:55-63, 2006
5. Azzarelli B, Miravalle L, Vidal R: Immunolocalization of the oligodendrocyte transcription factor 1 (Olig1) in brain tumors. J Neuropathol Exp Neurol 63:170-179, 2004

6. Balss J, Meyer J, Mueller W, Korshunov A, Hartmann C, von Deimling A: Analysis of the IDH1 codon 132 mutation in brain tumors. Acta Neuropathol 116:597-602, 2008

7. Barbashina V, Salazar P, Holland EC, Rosenblum MK, Ladanyi M: Allelic losses at 1p36 and 19q13 in gliomas: correlation with histologic classification, definition of a $150-\mathrm{kb}$ minimal deleted region on 1p36, and evaluation of CAMTA1 as a candidate tumor suppressor gene. Clin Cancer Res 11: 1119-1128, 2005

8. Barnett GH (ed): High-Grade Gliomas: Diagnosis and Treatment. Totowa, NJ: Humana Press, 2007

9. Bauman GS, Ino Y, Ueki K, Zlatescu MC, Fisher BJ, Macdonald DR, et al: Allelic loss of chromosome 1p and radiotherapy plus chemotherapy in patients with oligodendrogliomas. Int J Radiat Oncol Biol Phys 48:825-830, 2000

10. Bello MJ, de Campos JM, Vaquero J, Ruiz-Barnés P, Kusak ME, Sarasa JL, et al: hRAD54 gene and 1p high-resolution deletion-mapping analyses in oligodendrogliomas. Cancer Genet Cytogenet 116:142-147, 2000

11. Bello MJ, Vaquero J, de Campos JM, Kusak ME, Sarasa JL, Saez-Castresana J, et al: Molecular analysis of chromosome 1 abnormalities in human gliomas reveals frequent loss of $1 \mathrm{p}$ in oligodendroglial tumors. Int J Cancer 57:172-175, 1994

12. Besleaga R, Montesinos-Rongen M, Perez-Tur J, Siebert R, Deckert M: Expression of the LGI1 gene product in astrocytic gliomas: downregulation with malignant progression. Virchows Arch 443:561-564, 2003

13. Bethke L, Webb E, Murray A, Schoemaker M, Johansen C, Christensen HC, et al: Comprehensive analysis of the role of DNA repair gene polymorphisms on risk of glioma. Hum Mol Genet 17:800-805, 2008

14. Bhattacharjee MB, Armstrong DD, Vogel H, Cooley LD: Cytogenetic analysis of 120 primary pediatric brain tumors and literature review. Cancer Genet Cytogenet 97:39-53, 1997

15. Bögler O, Huang HJ, Kleihues P, Cavenee WK: The p53 gene and its role in human brain tumors. Glia 15:308-327, 1995

16. Boulay JL, Miserez AR, Zweifel C, Sivasankaran B, Kana V, Ghaffari A, et al: Loss of NOTCH2 positively predicts survival in subgroups of human glial brain tumors. PLoS ONE 2:e576, 2007

17. Broniscer A, Baker SJ, West AN, Fraser MM, Proko E, Kocak $\mathrm{M}$, et al: Clinical and molecular characteristics of malignant transformation of low-grade glioma in children. J Clin Oncol 25:682-689, 2007

18. Cairncross JG, Ueki K, Zlatescu MC, Lisle DK, Finkelstein DM, Hammond RR, et al: Specific genetic predictors of chemotherapeutic response and survival in patients with anaplastic oligodendrogliomas. J Natl Cancer Inst 90:1473-1479, 1998

19. Central Brain Tumor Registry of the United States: CBTRUS Statistical Report: Primary Brain and Central Nervous System Tumors Diagnosed in the United States in 20042007. (http://www.cbtrus.org/2011-NPCR-SEER/WEB-0407Report-3-3-2011.pdf) [Accessed December 12, 2012]

20. Cooper LA, Gutman DA, Long Q, Johnson BA, Cholleti SR, Kurc T, et al: The proneural molecular signature is enriched in oligodendrogliomas and predicts improved survival among diffuse gliomas. PLoS ONE 5:e12548, 2010

21. Costello JF, Plass C, Cavenee WK: Aberrant methylation of genes in low-grade astrocytomas. Brain Tumor Pathol 17: 49-56, 2000

22. Crawford JR, Santi MR, Thorarinsdottir HK, Cornelison R, Rushing EJ, Zhang H, et al: Detection of human herpesvirus-6 variants in pediatric brain tumors: association of viral antigen in low grade gliomas. J Clin Virol 46:37-42, 2009 
23. Di Rocco F, Carroll RS, Zhang J, Black PM: Platelet-derived growth factor and its receptor expression in human oligodendrogliomas. Neurosurgery 42:341-346, 1998

24. di Tomaso E, London N, Fuja D, Logie J, Tyrrell JA, Kamoun $\mathrm{W}$, et al: PDGF-C induces maturation of blood vessels in a model of glioblastoma and attenuates the response to antiVEGF treatment. PLoS ONE 4:e5123, 2009

25. Dias-Santagata D, Lam Q, Vernovsky K, Vena N, Lennerz $\mathrm{JK}$, Borger DR, et al: BRAF V600E mutations are common in pleomorphic xanthoastrocytoma: diagnostic and therapeutic implications. PLoS ONE 6:e17948, 2011

26. Dong S, Pang JC, Hu J, Zhou LF, Ng HK: Transcriptional inactivation of TP73 expression in oligodendroglial tumors. Int J Cancer 98:370-375, 2002

27. Dong SM, Pang JC, Poon WS, Hu J, To KF, Chang AR, et al: Concurrent hypermethylation of multiple genes is associated with grade of oligodendroglial tumors. J Neuropathol Exp Neurol 60:808-816, 2001

28. Ekstrand AJ, Sugawa N, James CD, Collins VP: Amplified and rearranged epidermal growth factor receptor genes in human glioblastomas reveal deletions of sequences encoding portions of the N-and/or C-terminal tails. Proc Natl Acad Sci U S A 89:4309-4313, 1992

29. Eoli M, Bissola L, Bruzzone MG, Pollo B, Maccagnano C, De Simone T, et al: Reclassification of oligoastrocytomas by loss of heterozygosity studies. Int J Cancer 119:84-90, 2006

30. Everhard S, Kaloshi G, Crinière E, Benouaich-Amiel A, Lejeune J, Marie Y, et al: MGMT methylation: a marker of response to temozolomide in low-grade gliomas. Ann Neurol 60:740-743, 2006

31. Felsberg J, Erkwoh A, Sabel MC, Kirsch L, Fimmers R, Blaschke B, et al: Oligodendroglial tumors: refinement of candidate regions on chromosome arm $1 \mathrm{p}$ and correlation of 1p/19q status with survival. Brain Pathol 14:121-130, 2004

32. Fouladi M, Jenkins J, Burger P, Langston J, Merchant T, Heideman R, et al: Pleomorphic xanthoastrocytoma: favorable outcome after complete surgical resection. Neuro Oncol 3: 184-192, 2001

33. Fuller GN, Hess KR, Rhee CH, Yung WK, Sawaya RA, Bruner JM, et al: Molecular classification of human diffuse gliomas by multidimensional scaling analysis of gene expression profiles parallels morphology-based classification, correlates with survival, and reveals clinically-relevant novel glioma subsets. Brain Pathol 12:108-116, 2002

34. Geisbrecht BV, Gould SJ: The human PICD gene encodes a cytoplasmic and peroxisomal NADP(+)-dependent isocitrate dehydrogenase. J Biol Chem 274:30527-30533, 1999

35. Giannini C, Hebrink D, Scheithauer BW, Dei Tos AP, James $\mathrm{CD}$ : Analysis of p53 mutation and expression in pleomorphic xanthoastrocytoma. Neurogenetics 3:159-162, 2001

36. Giannini C, Scheithauer BW, Lopes MB, Hirose T, Kros JM, VandenBerg SR: Immunophenotype of pleomorphic xanthoastrocytoma. Am J Surg Pathol 26:479-485, 2002

37. Godard S, Getz G, Delorenzi M, Farmer P, Kobayashi H, Desbaillets I, et al: Classification of human astrocytic gliomas on the basis of gene expression: a correlated group of genes with angiogenic activity emerges as a strong predictor of subtypes. Cancer Res 63:6613-6625, 2003

38. Grau E, Balaguer J, Canete A, Martinez F, Orellana C, Oltra $\mathrm{S}$, et al: Subtelomeric analysis of pediatric astrocytoma: subchromosomal instability is a distinctive feature of pleomorphic xanthoastrocytoma. J Neurooncol 93:175-182, 2009

39. Gravendeel LA, Kloosterhof NK, Bralten LB, van Marion R, Dubbink HJ, Dinjens W, et al: Segregation of non-p.R132H mutations in IDH1 in distinct molecular subtypes of glioma. Hum Mutat 31:E1186-E1199, 2010

40. Griffin CA, Burger P, Morsberger L, Yonescu R, Swierczynski S, Weingart JD, et al: Identification of $\operatorname{der}(1 ; 19)(\mathrm{q} 10 ; \mathrm{p} 10)$ in five oligodendrogliomas suggests mechanism of concurrent 1p and 19q loss. J Neuropathol Exp Neurol 65:988-994, 2006

41. Guha A, Glowacka D, Carroll R, Dashner K, Black PM, Stiles $\mathrm{CD}$ : Expression of platelet derived growth factor and platelet derived growth factor receptor mRNA in a glioblastoma from a patient with Li-Fraumeni syndrome. J Neurol Neurosurg Psychiatry 58:711-714, 1995

42. Gupta M, Djalilvand A, Brat DJ: Clarifying the diffuse gliomas: an update on the morphologic features and markers that discriminate oligodendroglioma from astrocytoma. Am J Clin Pathol 124:755-768, 2005

43. Gutmann DH, Hedrick NM, Li J, Nagarajan R, Perry A, Watson MA: Comparative gene expression profile analysis of neurofibromatosis 1-associated and sporadic pilocytic astrocytomas. Cancer Res 62:2085-2091, 2002

44. Hägerstrand D, Smits A, Eriksson A, Sigurdardottir S, Olofsson T, Hartman M, et al: Gene expression analyses of grade II gliomas and identification of rPTPbeta/zeta as a candidate oligodendroglioma marker. Neuro Oncol 10:2-9, 2008

45. Hartmann C, Johnk L, Kitange G, Wu Y, Ashworth LK, Jenkins RB, et al: Transcript map of the 3.7-Mb D19S112D19S246 candidate tumor suppressor region on the long arm of chromosome 19. Cancer Res 62:4100-4108, 2002

46. Hartmann C, Mueller W, von Deimling A: Pathology and molecular genetics of oligodendroglial tumors. J Mol Med (Berl) 82:638-655, 2004

47. Hermanson M, Funa K, Hartman M, Claesson-Welsh L, Heldin $\mathrm{CH}$, Westermark B, et al: Platelet-derived growth factor and its receptors in human glioma tissue: expression of messenger RNA and protein suggests the presence of autocrine and paracrine loops. Cancer Res 52:3213-3219, 1992

48. Hilton DA, Love S, Barber R, Ellison D, Sandeman DR: Accumulation of p53 and Ki-67 expression do not predict survival in patients with fibrillary astrocytomas or the response of these tumors to radiotherapy. Neurosurgery 42:724-729, 1998

49. Hirose T, Giannini C, Scheithauer BW: Ultrastructural features of pleomorphic xanthoastrocytoma: a comparative study with glioblastoma multiforme. Ultrastruct Pathol 25:469478, 2001

50. Hirose T, Ishizawa K, Sugiyama K, Kageji T, Ueki K, Kannuki S: Pleomorphic xanthoastrocytoma: a comparative pathological study between conventional and anaplastic types. Histopathology 52:183-193, 2008

51. Hoang-Xuan K, Capelle L, Kujas M, Taillibert S, Duffau H, Lejeune J, et al: Temozolomide as initial treatment for adults with low-grade oligodendrogliomas or oligoastrocytomas and correlation with chromosome 1p deletions. J Clin Oncol 22: 3133-3138, 2004

52. Hong C, Bollen AW, Costello JF: The contribution of genetic and epigenetic mechanisms to gene silencing in oligodendrogliomas. Cancer Res 63:7600-7605, 2003

53. Hosokawa Y, Tsuchihashi Y, Okabe H, Toyama M, Namura $\mathrm{K}$, Kuga M, et al: Pleomorphic xanthoastrocytoma. Ultrastructural, immunohistochemical, and DNA cytofluorometric study of a case. Cancer 68:853-859, 1991

54. Houillier C, Lejeune J, Benouaich-Amiel A, Laigle-Donadey F, Criniere E, Mokhtari K, et al: Prognostic impact of molecular markers in a series of 220 primary glioblastomas. Cancer 106:2218-2223, 2006

55. Huang H, Colella S, Kurrer M, Yonekawa Y, Kleihues P, Ohgaki $\mathrm{H}$ : Gene expression profiling of low-grade diffuse astrocytomas by cDNA arrays. Cancer Res 60:6868-6874, 2000

56. Huang H, Hara A, Homma T, Yonekawa Y, Ohgaki H: Altered expression of immune defense genes in pilocytic astrocytomas. J Neuropathol Exp Neurol 64:891-901, 2005

57. Huang L, Jiang T, Yuan F, Li GL, Cui Y, Liu EZ, et al: Cor- 
relation of chromosomes $1 p$ and $19 q$ status and expressions of O6-methylguanine DNA methyltransferase (MGMT), p53 and $\mathrm{Ki}-67$ in diffuse gliomas of World Health Organization (WHO) grades II and III: a clinicopathological study. Neuropathol Appl Neurobiol 35:367-379, 2009

58. Hunter S, Young A, Olson J, Brat DJ, Bowers G, Wilcox JN, et al: Differential expression between pilocytic and anaplastic astrocytomas: identification of apolipoprotein D as a marker for low-grade, non-infiltrating primary CNS neoplasms. J Neuropathol Exp Neurol 61:275-281, 2002

59. Husemann K, Wolter M, Büschges R, Boström J, Sabel M, Reifenberger G: Identification of two distinct deleted regions on the short arm of chromosome 1 and rare mutation of the CDKN2C gene from 1p32 in oligodendroglial tumors. J Neuropathol Exp Neurol 58:1041-1050, 1999

60. Ichimura K, Bolin MB, Goike HM, Schmidt EE, Moshref A, Collins VP: Deregulation of the p14ARF/MDM2/p53 pathway is a prerequisite for human astrocytic gliomas with G1-S transition control gene abnormalities. Cancer Res 60:417424, 2000

61. Ichimura K, Pearson DM, Kocialkowski S, Bäcklund LM, Chan R, Jones DT, et al: IDH1 mutations are present in the majority of common adult gliomas but rare in primary glioblastomas. Neuro Oncol 11:341-347, 2009

62. Im SH, Chung CK, Kim SK, Cho BK, Kim MK, Chi JG: Pleomorphic xanthoastrocytoma: a developmental glioneuronal tumor with prominent glioproliferative changes. J Neurooncol 66:17-27, 2004

63. Ino Y, Zlatescu MC, Sasaki H, Macdonald DR, Stemmer-Rachamimov AO, Jhung S, et al: Long survival and therapeutic responses in patients with histologically disparate high-grade gliomas demonstrating chromosome 1p loss. J Neurosurg 92:983-990, 2000

64. Inoue R, Isono M, Abe M, Abe T, Kobayashi H: A genotype of the polymorphic DNA repair gene MGMT is associated with de novo glioblastoma. Neurol Res 25:875-879, 2003

65. Ishii N, Tada M, Hamou MF, Janzer RC, Meagher-Villemure $\mathrm{K}$, Wiestler OD, et al: Cells with TP53 mutations in low grade astrocytic tumors evolve clonally to malignancy and are an unfavorable prognostic factor. Oncogene 18:5870-5878, 1999

66. James CD, Carlbom E, Nordenskjold M, Collins VP, Cavenee WK: Mitotic recombination of chromosome 17 in astrocytomas. Proc Natl Acad Sci U S A 86:2858-2862, 1989

67. Jenkins RB, Blair H, Ballman KV, Giannini C, Arusell RM, Law M, et al: A $\mathrm{t}(1 ; 19)(\mathrm{q} 10 ; \mathrm{p} 10)$ mediates the combined deletions of $1 p$ and $19 q$ and predicts a better prognosis of patients with oligodendroglioma. Cancer Res 66:9852-9861, 2006

68. Jeon YK, Cheon JE, Kim SK, Wang KC, Cho BK, Park SH: Clinicopathological features and global genomic copy number alterations of pilomyxoid astrocytoma in the hypothalamus/ optic pathway: comparative analysis with pilocytic astrocytoma using array-based comparative genomic hybridization. Mod Pathol 21:1345-1356, 2008

69. Jeuken JW, Sprenger SH, Boerman RH, von Deimling A, Teepen HL, van Overbeeke JJ, et al: Subtyping of oligo-astrocytic tumours by comparative genomic hybridization. J Pathol 194:81-87, 2001

70. Jeuken JW, von Deimling A, Wesseling P: Molecular pathogenesis of oligodendroglial tumors. J Neurooncol 70:161181,2004

71. Jiang X, Yu Y, Yang HW, Agar NY, Frado L, Johnson MD: The imprinted gene PEG3 inhibits Wnt signaling and regulates glioma growth. J Biol Chem 285:8472-8480, 2010

72. Kaloshi G, Benouaich-Amiel A, Diakite F, Taillibert S, Lejeune J, Laigle-Donadey F, et al: Temozolomide for lowgrade gliomas: predictive impact of $1 \mathrm{p} / 19 \mathrm{q}$ loss on response and outcome. Neurology 68:1831-1836, 2007

73. Kamijo T, Weber JD, Zambetti G, Zindy F, Roussel MF, Sherr
CJ: Functional and physical interactions of the ARF tumor suppressor with p53 and Mdm2. Proc Natl Acad Sci U S A 95:8292-8297, 1998

74. Kanner AA, Staugaitis SM, Castilla EA, Chernova O, Prayson RA, Vogelbaum MA, et al: The impact of genotype on outcome in oligodendroglioma: validation of the loss of chromosome arm $1 p$ as an important factor in clinical decision making. J Neurosurg 104:542-550, 2006

75. Kaulich K, Blaschke B, Nümann A, von Deimling A, Wiestler OD, Weber RG, et al: Genetic alterations commonly found in diffusely infiltrating cerebral gliomas are rare or absent in pleomorphic xanthoastrocytomas. J Neuropathol Exp Neurol 61:1092-1099, 2002

76. Kepes JJ, Rubinstein LJ, Eng LF: Pleomorphic xanthoastrocytoma: a distinctive meningocerebral glioma of young subjects with relatively favorable prognosis. A study of 12 cases. Cancer 44:1839-1852, 1979

77. Khatua S, Peterson KM, Brown KM, Lawlor C, Santi MR, LaFleur B, et al: Overexpression of the EGFR/FKBP12/HIF2alpha pathway identified in childhood astrocytomas by angiogenesis gene profiling. Cancer Res 63:1865-1870, 2003

78. Kim YH, Nobusawa S, Mittelbronn M, Paulus W, Brokinkel B, Keyvani K, et al: Molecular classification of low-grade diffuse gliomas. Am J Pathol 177:2708-2714, 2010

79. Kitange G, Misra A, Law M, Passe S, Kollmeyer TM, Maurer $\mathrm{M}$, et al: Chromosomal imbalances detected by array comparative genomic hybridization in human oligodendrogliomas and mixed oligoastrocytomas. Genes Chromosomes Cancer 42:68-77, 2005

80. Korshunov A, Meyer J, Capper D, Christians A, Remke M, Witt $\mathrm{H}$, et al: Combined molecular analysis of BRAF and IDH1 distinguishes pilocytic astrocytoma from diffuse astrocytoma. Acta Neuropathol 118:401-405, 2009

81. Kraus JA, Koopmann J, Kaskel P, Maintz D, Brandner S, Schramm J, et al: Shared allelic losses on chromosomes 1p and $19 \mathrm{q}$ suggest a common origin of oligodendroglioma and oligoastrocytoma. J Neuropathol Exp Neurol 54:91-95, 1995

82. Kujas M, Lejeune J, Benouaich-Amiel A, Crinière E, LaigleDonadey F, Marie Y, et al: Chromosome 1p loss: a favorable prognostic factor in low-grade gliomas. Ann Neurol 58:322326, 2005

83. Kunitz A, Wolter M, van den Boom J, Felsberg J, Tews B, Hahn M, et al: DNA hypermethylation and aberrant expression of the EMP3 gene at 19q13.3 in Human Gliomas. Brain Pathol 17:363-370, 2007

84. Labussière M, Idbaih A, Wang XW, Marie Y, Boisselier B, Falet C, et al: All the 1p19q codeleted gliomas are mutated on IDH1 or IDH2. Neurology 74:1886-1890, 2010

85. Levin N, Lavon I, Zelikovitsh B, Fuchs D, Bokstein F, Fellig Y, et al: Progressive low-grade oligodendrogliomas: response to temozolomide and correlation between genetic profile and O6-methylguanine DNA methyltransferase protein expression. Cancer 106:1759-1765, 2006

86. Li YS, Ramsay DA, Fan YS, Armstrong RF, Del Maestro RF: Cytogenetic evidence that a tumor suppressor gene in the long arm of chromosome 1 contributes to glioma growth. Cancer Genet Cytogenet 84:46-50, 1995

87. Ligon KL, Alberta JA, Kho AT, Weiss J, Kwaan MR, Nutt CL, et al: The oligodendroglial lineage marker OLIG2 is universally expressed in diffuse gliomas. J Neuropathol Exp Neurol 63:499-509, 2004

88. Liu L, Bäcklund LM, Nilsson BR, Grandér D, Ichimura K, Goike HM, et al: Clinical significance of EGFR amplification and the aberrant EGFRvIII transcript in conventionally treated astrocytic gliomas. J Mol Med (Berl) 83:917-926, 2005

89. Ljubimova JY, Lakhter AJ, Loksh A, Yong WH, Riedinger MS, Miner JH, et al: Overexpression of alpha4 chain-containing laminins in human glial tumors identified by gene microarray analysis. Cancer Res 61:5601-5610, 2001 
90. Lokker NA, Sullivan CM, Hollenbach SJ, Israel MA, Giese NA: Platelet-derived growth factor (PDGF) autocrine signaling regulates survival and mitogenic pathways in glioblastoma cells: evidence that the novel PDGF-C and PDGF-D ligands may play a role in the development of brain tumors. Cancer Res 62:3729-3735, 2002

91. Louis DN, Ohgaki H, Wiestler OD, Cavenee WK (eds): WHO Classification of Tumours of the Central Nervous System. Lyon, France: IARC Press, 2007

92. Lu QR, Park JK, Noll E, Chan JA, Alberta J, Yuk D, et al: Oligodendrocyte lineage genes (OLIG) as molecular markers for human glial brain tumors. Proc Natl Acad Sci U S A 98: 10851-10856, 2001

93. Lu QR, Sun T, Zhu Z, Ma N, Garcia M, Stiles CD, et al: Common developmental requirement for Olig function indicates a motor neuron/oligodendrocyte connection. Cell 109:75-86, 2002

94. Maintz D, Fiedler K, Koopmann J, Rollbrocker B, Nechev S, Lenartz D, et al: Molecular genetic evidence for subtypes of oligoastrocytomas. J Neuropathol Exp Neurol 56:1098-1104, 1997

95. Marko NF, Prayson RA, Barnett GH, Weil RJ: Integrated molecular analysis suggests a three-class model for low-grade gliomas: a proof-of-concept study. Genomics 95: 16-24, 2010

96. Marko NF, Toms SA, Barnett GH, Weil R: Genomic expression patterns distinguish long-term from short-term glioblastoma survivors: a preliminary feasibility study. Genomics 91:395-406, 2008

97. Martinez-Diaz H, Kleinschmidt-DeMasters BK, Powell SZ, Yachnis AT: Giant cell glioblastoma and pleomorphic xanthoastrocytoma show different immunohistochemical profiles for neuronal antigens and p53 but share reactivity for class III betatubulin. Arch Pathol Lab Med 127:1187-1191, 2003

98. Matsumoto K, Suzuki SO, Fukui M, Iwaki T: Accumulation of MDM2 in pleomorphic xanthoastrocytomas. Pathol Int 54: 387-391, 2004

99. Matyja E, Kroh H, Taraszewska A, Nagańska E, Zabek M, Marchel A: Expression of macrophage/histiocytic antigens in pleomorphic xanthoastrocytomas. Folia Neuropathol 41:8995, 2003

100. McDonald JM, Dunlap S, Cogdell D, Dunmire V, Wei Q, Starzinski-Powitz A, et al: The SHREW1 gene, frequently deleted in oligodendrogliomas, functions to inhibit cell adhesion and migration. Cancer Biol Ther 5:300-304, 2006

101. McDonald JM, Dunmire V, Taylor E, Sawaya R, Bruner J, Fuller GN, et al: Attenuated expression of DFFB is a hallmark of oligodendrogliomas with 1p-allelic loss. Mol Cancer 4:35, 2005

102. McLendon RE, Herndon JE II, West B, Reardon D, Wiltshire R, Rasheed BK, et al: Survival analysis of presumptive prognostic markers among oligodendrogliomas. Cancer 104:1693-1699, 2005

103. Meléndez B, Fiaño C, Ruano Y, Hernández-Moneo JL, Mollejo M, Martinez P: BCR gene disruption in a pilomyxoid astrocytoma. Neuropathology 26:442-446, 2006

104. Metellus P, Coulibaly B, Colin C, de Paula AM, Vasiljevic A, Taieb D, et al: Absence of IDH mutation identifies a novel radiologic and molecular subtype of WHO grade II gliomas with dismal prognosis. Acta Neuropathol 120:719-729, 2010

105. Miwa T, Hirose Y, Sasaki H, Ezaki T, Yoshida K, Kawase T: Single-copy gain of chromosome 1q is a negative prognostic marker in pediatric nonependymal, nonpilocytic gliomas. Neurosurgery 68:206-212, 2011

106. Miyakawa A, Ichimura K, Schmidt EE, Varmeh-Ziaie S, Collins VP: Multiple deleted regions on the long arm of chromosome 6 in astrocytic tumours. Br J Cancer 82:543-549, 2000

107. Möllemann M, Wolter M, Felsberg J, Collins VP, Reifenberger G: Frequent promoter hypermethylation and low expression of the MGMT gene in oligodendroglial tumors. Int J Cancer 113: 379-385, 2005
108. Mora J, Cheung NK, Chen L, Qin J, Gerald W: Loss of heterozygosity at $19 \mathrm{q} 13.3$ is associated with locally aggressive neuroblastoma. Clin Cancer Res 7:1358-1361, 2001

109. Mueller W, Hartmann C, Hoffmann A, Lanksch W, Kiwit J, Tonn J, et al: Genetic signature of oligoastrocytomas correlates with tumor location and denotes distinct molecular subsets. Am J Pathol 161:313-319, 2002

110. Munoz EL, Eberhard DA, Lopes MBS, Schnieder BF, GonzalezFernandez F, VandenBerg S: Proliferative activity and p53 mutation as prognostic indicators in pleomorphic xanthoastrocytoma. A clinicopathologic study of six cases. J Neuropathol Exp Neurol 55:606, 1996

111. Murray JC, Donahue DJ, Malik SI, Dzurik YB, Braly EZ, Dougherty MJ, et al: Temporal lobe pleomorphic xanthoastrocytoma and acquired BRAF mutation in an adolescent with the constitutional 22q11.2 deletion syndrome. J Neurooncol 102: 509-514, 2011

112. Myal Y, Del Bigio MR, Rhodes RH: Age-related differences in $1 \mathrm{p}$ and $19 \mathrm{q}$ deletions in oligodendrogliomas. BMC Clin Pathol 3:6, 2003

113. Nakamura M, Shimada K, Ishida E, Higuchi T, Nakase H, Sakaki T, et al: Molecular pathogenesis of pediatric astrocytic tumors. Neuro Oncol 9:113-123, 2007

114. Nakamura M, Watanabe T, Klangby U, Asker C, Wiman K, Yonekawa Y, et al: p14ARF deletion and methylation in genetic pathways to glioblastomas. Brain Pathol 11:159-168, 2001

115. Narahara K, Kimura S, Kikkawa K, Takahashi Y, Wakita Y, Kasai R, et al: Probable assignment of soluble isocitrate dehydrogenase (IDH1) to 2q33.3. Hum Genet 71:37-40, 1985

116. Nishizaki T, Ozaki S, Harada K, Ito H, Arai H, Beppu T, et al: Investigation of genetic alterations associated with the grade of astrocytic tumor by comparative genomic hybridization. Genes Chromosomes Cancer 21:340-346, 1998

117. Ohgaki H, Dessen P, Jourde B, Horstmann S, Nishikawa T, Di Patre PL, et al: Genetic pathways to glioblastoma: a populationbased study. Cancer Res 64:6892-6899, 2004

118. Ohgaki H, Kleihues P: Genetic alterations and signaling pathways in the evolution of gliomas. Cancer Sci 100:2235-2241, 2009

119. Ohgaki H, Kleihues P: Population-based studies on incidence, survival rates, and genetic alterations in astrocytic and oligodendroglial gliomas. J Neuropathol Exp Neurol 64:479-489, 2005

120. Ohnishi A, Sawa H, Tsuda M, Sawamura Y, Itoh T, Iwasaki $\mathrm{Y}$, et al: Expression of the oligodendroglial lineage-associated markers Olig1 and Olig2 in different types of human gliomas. J Neuropathol Exp Neurol 62:1052-1059, 2003

121. Okamoto Y, Di Patre PL, Burkhard C, Horstmann S, Jourde B, Fahey M, et al: Population-based study on incidence, survival rates, and genetic alterations of low-grade diffuse astrocytomas and oligodendrogliomas. Acta Neuropathol 108:49-56, 2004

122. Orellana C, Hernandez-Martí M, Martínez F, Castel V, Millán JM, Alvarez-Garijo JA, et al: Pediatric brain tumors: loss of heterozygosity at $17 \mathrm{p}$ and TP53 gene mutations. Cancer Genet Cytogenet 102:93-99, 1998

123. Orr LC, Fleitz J, McGavran L, Wyatt-Ashmead J, Handler M, Foreman NK: Cytogenetics in pediatric low-grade astrocytomas. Med Pediatr Oncol 38:173-177, 2002

124. Otero JJ, Rowitch D, Vandenberg S: OLIG2 is differentially expressed in pediatric astrocytic and in ependymal neoplasms. J Neurooncol 104:423-438, 2011

125. Parsons DW, Jones S, Zhang X, Lin JC, Leary RJ, Angenendt $\mathrm{P}$, et al: An integrated genomic analysis of human glioblastoma multiforme. Science 321:1807-1812, 2008

126. Paulus W, Lisle DK, Tonn JC, Wolf HK, Roggendorf W, Reeves SA, et al: Molecular genetic alterations in pleomorphic xanthoastrocytoma. Acta Neuropathol 91:293-297, 1996

127. Peraud A, Kreth FW, Wiestler OD, Kleihues P, Reulen HJ: Prognostic impact of TP53 mutations and P53 protein overex- 
pression in supratentorial WHO grade II astrocytomas and oligoastrocytomas. Clin Cancer Res 8: 1117-1124, 2002

128. Pietrak B, Zhao H, Qi H, Quinn C, Gao E, Boyer JG, et al: A tale of two subunits: how the neomorphic R132H IDH1 mutation enhances production of $\alpha \mathrm{HG}$. Biochemistry 50:4804-4812, 2011

129. Pollack IF, Finkelstein SD, Burnham J, Hamilton RL, Yates AJ, Holmes EJ, et al: Association between chromosome 1p and 19q loss and outcome in pediatric malignant gliomas: results from the CCG-945 cohort. Pediatr Neurosurg 39:114-121, 2003

130. Powell SZ, Yachnis AT, Rorke LB, Rojiani AM, Eskin TA: Divergent differentiation in pleomorphic xanthoastrocytoma. Evidence for a neuronal element and possible relationship to ganglion cell tumors. Am J Surg Pathol 20:80-85, 1996

131. Rao AA, Laack NN, Giannini C, Wetmore C: Pleomorphic xanthoastrocytoma in children and adolescents. Pediatr Blood Cancer 55:290-294, 2010

132. Rasheed BK, McLendon RE, Herndon JE, Friedman HS, Friedman AH, Bigner DD, et al: Alterations of the TP53 gene in human gliomas. Cancer Res 54:1324-1330, 1994

133. Rees J, Wen P (eds): Neuro-Oncology. Philadelphia: Saunders Elsevier, 2010

134. Reifenberger G, Collins VP: Pathology and molecular genetics of astrocytic gliomas. J Mol Med (Berl) 82:656-670, 2004

135. Reifenberger G, Kaulich K, Wiestler OD, Blümcke I: Expression of the CD34 antigen in pleomorphic xanthoastrocytomas. Acta Neuropathol 105:358-364, 2003

136. Reifenberger G, Louis DN: Oligodendroglioma: toward molecular definitions in diagnostic neuro-oncology. J Neuropathol Exp Neurol 62:111-126, 2003

137. Reifenberger J, Reifenberger G, Ichimura K, Schmidt EE, Wechsler W, Collins VP: Epidermal growth factor receptor expression in oligodendroglial tumors. Am J Pathol 149:29-35, 1996

138. Reifenberger J, Reifenberger G, Liu L, James CD, Wechsler W, Collins VP: Molecular genetic analysis of oligodendroglial tumors shows preferential allelic deletions on 19q and 1p. Am J Pathol 145:1175-1190, 1994

139. Rickman DS, Bobek MP, Misek DE, Kuick R, Blaivas M, Kurnit $\mathrm{DM}$, et al: Distinctive molecular profiles of high-grade and lowgrade gliomas based on oligonucleotide microarray analysis. Cancer Res 61:6885-6891, 2001

140. Riemenschneider MJ, Koy TH, Reifenberger G: Expression of oligodendrocyte lineage genes in oligodendroglial and astrocytic gliomas. Acta Neuropathol 107:277-282, 2004

141. Roberts P, Chumas PD, Picton S, Bridges L, Livingstone JH, Sheridan E: A review of the cytogenetics of 58 pediatric brain tumors. Cancer Genet Cytogenet 131:1-12, 2001

142. Rodriguez FJ, Giannini C, Asmann YW, Sharma MK, Perry A, Tibbetts KM, et al: Gene expression profiling of NF-1-associated and sporadic pilocytic astrocytoma identifies aldehyde dehydrogenase 1 family member L1 (ALDH1L1) as an underexpressed candidate biomarker in aggressive subtypes. J Neuropathol Exp Neurol 67:1194-1204, 2008

143. Rorive S, Maris C, Debeir O, Sandras F, Vidaud M, Bièche I, et al: Exploring the distinctive biological characteristics of pilocytic and low-grade diffuse astrocytomas using microarray gene expression profiles. J Neuropathol Exp Neurol 65:794-807, 2006

144. Rosenberg JE, Lisle DK, Burwick JA, Ueki K, von Deimling A, Mohrenweiser HW, et al: Refined deletion mapping of the chromosome 19q glioma tumor suppressor gene to the D19S412STD interval. Oncogene 13:2483-2485, 1996

145. Rossi MR, Gaile D, Laduca J, Matsui S, Conroy J, McQuaid D, et al: Identification of consistent novel submegabase deletions in low-grade oligodendrogliomas using array-based comparative genomic hybridization. Genes Chromosomes Cancer 44: 85-96, 2005
146. Rowitch DH, Lu QR, Kessaris N, Richardson WD: An 'oligarchy' rules neural development. Trends Neurosci 25:417-422, 2002

147. Rush SZ, Abel TW, Valadez JG, Pearson M, Cooper MK: Activation of the Hedgehog pathway in pilocytic astrocytomas. Neuro Oncol 12:790-798, 2010

148. Sallinen SL, Sallinen PK, Haapasalo HK, Helin HJ, Helén PT, Schraml P, et al: Identification of differentially expressed genes in human gliomas by DNA microarray and tissue chip techniques. Cancer Res 60:6617-6622, 2000

149. Sanson M, Marie Y, Paris S, Idbaih A, Laffaire J, Ducray F, et al: Isocitrate dehydrogenase 1 codon 132 mutation is an important prognostic biomarker in gliomas. J Clin Oncol 27:4150-4154, 2009

150. Sasaki H, Zlatescu MC, Betensky RA, Johnk LB, Cutone AN, Cairncross JG, et al: Histopathological-molecular genetic correlations in referral pathologist-diagnosed low-grade "oligodendroglioma.” J Neuropathol Exp Neurol 61:58-63, 2002

151. Sawyer JR, Roloson GJ, Chadduck WM, Boop FA: Cytogenetic findings in a pleomorphic xanthoastrocytoma. Cancer Genet Cytogenet 55:225-230, 1991

152. Sawyer JR, Thomas EL, Roloson GJ, Chadduck WM, Boop FA: Telomeric associations evolving to ring chromosomes in a recurrent pleomorphic xanthoastrocytoma. Cancer Genet Cytogenet 60:152-157, 1992

153. Schiff D, Brown PD, Giannini C: Outcome in adult low-grade glioma: the impact of prognostic factors and treatment. Neurology 69:1366-1373, 2007

154. Schindler G, Capper D, Meyer J, Janzarik W, Omran H, HeroldMende C, et al: Analysis of BRAF V600E mutation in 1,320 nervous system tumors reveals high mutation frequencies in pleomorphic xanthoastrocytoma, ganglioglioma and extra-cerebellar pilocytic astrocytoma. Acta Neuropathol 121:397-405, 2011

155. Schlessinger J: SH2/SH3 signaling proteins. Curr Opin Genet Dev 4:25-30, 1994

156. Schlierf B, Friedrich RP, Roerig P, Felsberg J, Reifenberger G, Wegner M: Expression of SoxE and SoxD genes in human gliomas. Neuropathol Appl Neurobiol 33:621-630, 2007

157. Schramm J (ed): Advances in Technical Standards in Neurosurgery. Volume 35: Low-Grade Gliomas. New York: Springer-Verlag, 2010

158. Schröck E, Blume C, Meffert MC, du Manoir S, Bersch W, Kiessling M, et al: Recurrent gain of chromosome arm 7q in low-grade astrocytic tumors studied by comparative genomic hybridization. Genes Chromosomes Cancer 15:199-205, 1996

159. Sherr CJ: Divorcing ARF and p53: an unsettled case. Nat Rev Cancer 6:663-673, 2006

160. Sidransky D, Mikkelsen T, Schwechheimer K, Rosenblum ML, Cavanee W, Vogelstein B: Clonal expansion of p53 mutant cells is associated with brain tumour progression. Nature 355: 846-847, 1992

161. Silber JR, Bobola MS, Ghatan S, Blank A, Kolstoe DD, Berger MS: O6-methylguanine-DNA methyltransferase activity in adult gliomas: relation to patient and tumor characteristics. Cancer Res 58:1068-1073, 1998

162. Smith JS, Alderete B, Minn Y, Borell TJ, Perry A, Mohapatra G, et al: Localization of common deletion regions on $1 p$ and $19 q$ in human gliomas and their association with histological subtype. Oncogene 18:4144-4152, 1999

163. Smith JS, Tachibana I, Passe SM, Huntley BK, Borell TJ, Iturria $\mathrm{N}$, et al: PTEN mutation, EGFR amplification, and outcome in patients with anaplastic astrocytoma and glioblastoma multiforme. J Natl Cancer Inst 93: 1246-1256, 2001

164. Smith JS, Tachibana I, Pohl U, Lee HK, Thanarajasingam U, Portier BP, et al: A transcript map of the chromosome 19q-arm glioma tumor suppressor region. Genomics 64:44-50, 2000

165. Stott FJ, Bates S, James MC, McConnell BB, Starborg M, Brookes S, et al: The alternative product from the human 
CDKN2A locus, p14(ARF), participates in a regulatory feedback loop with p53 and MDM2. EMBO J 17:5001-5014, 1998

166. Tabori U, Rienstein S, Dromi Y, Leider-Trejo L, Constantini S, Burstein Y, et al: Epidermal growth factor receptor gene amplification and expression in disseminated pediatric low-grade gliomas. J Neurosurg 103 (4 Suppl):357-361, 2005

167. Tekkök IH, Sav A: Anaplastic pleomorphic xanthoastrocytomas. Review of the literature with reference to malignancy potential. Pediatr Neurosurg 40:171-181, 2004

168. Tews B, Felsberg J, Hartmann C, Kunitz A, Hahn M, Toedt G, et al: Identification of novel oligodendroglioma-associated candidate tumor suppressor genes in 1p36 and 19q13 using microarray-based expression profiling. Int J Cancer 119:792-800, 2006

169. Tews B, Roerig P, Hartmann C, Hahn M, Felsberg J, Blaschke $\mathrm{B}$, et al: Hypermethylation and transcriptional downregulation of the CITED4 gene at 1p34.2 in oligodendroglial tumours with allelic losses on 1p and 19q. Oncogene 26:5010-5016, 2007

170. Trouillard O, Aguirre-Cruz L, Hoang-Xuan K, Marie Y, Delattre JY, Sanson M: Parental 19q loss and PEG3 expression in oligodendrogliomas. Cancer Genet Cytogenet 151:182-183, 2004

171. Tsutsumi S, Abe Y, Yasumoto Y, Ito M: Anaplastic pleomorphic xanthoastrocytoma with a component of anaplastic astrocytoma presenting as skull base tumor followed by downward extracranial extension. Case report. Neurol Med Chir (Tokyo) 50:1108-1112, 2010

172. Ueki K, Nishikawa R, Nakazato Y, Hirose T, Hirato J, Funada $\mathrm{N}$, et al: Correlation of histology and molecular genetic analysis of 1p, 19q, 10q, TP53, EGFR, CDK4, and CDKN2A in 91 astrocytic and oligodendroglial tumors. Clin Cancer Res 8: 196-201, 2002

173. Vajtai I, Varga Z: Prognostic markers of pleomorphic xanthoastrocytoma. Histopathology 33:391, 1998 (Letter)

174. van den Boom J, Wolter M, Kuick R, Misek DE, Youkilis AS, Wechsler DS, et al: Characterization of gene expression profiles associated with glioma progression using oligonucleotide-based microarray analysis and real-time reverse transcription-polymerase chain reaction. Am J Pathol 163:1033-1043, 2003

175. Varela M, Ranuncolo SM, Morand A, Lastiri J, De Kier Joffé EB, Puricelli LI, et al: EGF-R and PDGF-R, but not bcl-2, overexpression predict overall survival in patients with low-grade astrocytomas. J Surg Oncol 86:34-40, 2004

176. Vogazianou AP, Chan R, Bäcklund LM, Pearson DM, Liu L, Langford CF, et al: Distinct patterns of $1 p$ and $19 q$ alterations identify subtypes of human gliomas that have different prognoses. Neuro Oncol 12:664-678, 2010

177. von Deimling A (ed): Gliomas. Berlin: Springer-Verlag, 2009

178. von Deimling A, Eibl RH, Ohgaki H, Louis DN, von Ammon $\mathrm{K}$, Petersen I, et al: p53 mutations are associated with $17 \mathrm{p}$ allelic loss in grade II and grade III astrocytoma. Cancer Res 52:2987-2990, 1992

179. von Deimling A, Fimmers R, Schmidt MC, Bender B, Fassbender F, Nagel J, et al: Comprehensive allelotype and genetic anaysis of 466 human nervous system tumors. J Neuropathol Exp Neurol 59:544-558, 2000

180. von Deimling A, Louis DN, von Ammon K, Petersen I, Wiestler $\mathrm{OD}$, Seizinger BR: Evidence for a tumor suppressor gene on chromosome 19q associated with human astrocytomas, oligodendrogliomas, and mixed gliomas. Cancer Res 52:4277-4279, 1992

181. Waha A, Güntner S, Huang TH, Yan PS, Arslan B, Pietsch T, et al: Epigenetic silencing of the protocadherin family member PCDH-gamma-A11 in astrocytomas. Neoplasia 7:193-199, 2005

182. Walker C, du Plessis DG, Joyce KA, Fildes D, Gee A, Haylock $\mathrm{B}$, et al: Molecular pathology and clinical characteristics of oligodendroglial neoplasms. Ann Neurol 57:855-865, 2005

183. Ward SJ, Karakoula K, Phipps KP, Harkness W, Hayward R,
Thompson D, et al: Cytogenetic analysis of paediatric astrocytoma using comparative genomic hybridisation and fluorescence in-situ hybridisation. J Neurooncol 98:305-318, 2010

184. Wasdahl DA, Scheithauer BW, Andrews BT, Jeffrey RA Jr: Cerebellar pleomorphic xanthoastrocytoma: case report. Neurosurgery 35:947-951, 1994

185. Watanabe K, Peraud A, Gratas C, Wakai S, Kleihues P, Ohgaki $\mathrm{H}: \mathrm{p} 53$ and PTEN gene mutations in gemistocytic astrocytomas. Acta Neuropathol 95:559-564, 1998

186. Watanabe K, Sato K, Biernat W, Tachibana O, von Ammon K, Ogata $\mathrm{N}$, et al: Incidence and timing of $\mathrm{p} 53$ mutations during astrocytoma progression in patients with multiple biopsies. Clin Cancer Res 3:523-530, 1997

187. Watanabe K, Tachibana O, Sata K, Yonekawa Y, Kleihues P, Ohgaki H: Overexpression of the EGF receptor and p53 mutations are mutually exclusive in the evolution of primary and secondary glioblastomas. Brain Pathol 6:217-223, 1996

188. Watanabe T, Katayama Y, Yoshino A, Yachi K, Ohta T, Ogino A, et al: Aberrant hypermethylation of p14ARF and O6-methylguanine-DNA methyltransferase genes in astrocytoma progression. Brain Pathol 17:5-10, 2007

189. Watanabe T, Nakamura M, Kros JM, Burkhard C, Yonekawa $\mathrm{Y}$, Kleihues $\mathrm{P}$, et al: Phenotype versus genotype correlation in oligodendrogliomas and low-grade diffuse astrocytomas. Acta Neuropathol 103:267-275, 2002

190. Watanabe T, Nobusawa S, Kleihues P, Ohgaki H: IDH1 mutations are early events in the development of astrocytomas and oligodendrogliomas. Am J Pathol 174:1149-1153, 2009

191. Weber RG, Hoischen A, Ehrler M, Zipper P, Kaulich K, Blaschke B, et al: Frequent loss of chromosome 9, homozygous CDKN2A/p14(ARF)/CDKN2B deletion and low TSC1 mRNA expression in pleomorphic xanthoastrocytomas. Oncogene 26: 1088-1097, 2007

192. Weil KC, Berge MS, Sehgal A: Molecular characterization of a novel human brain tumor-associated gene BR-3. Anticancer Res 22:1467-1474, 2002

193. Wessels PH, Twijnstra A, Kessels AG, Krijne-Kubat B, Theunissen PH, Ummelen MI, et al: Gain of chromosome 7, as detected by in situ hybridization, strongly correlates with shorter survival in astrocytoma grade 2. Genes Chromosomes Cancer 33:279-284, 2002

194. Wiencke JK, Zheng S, Jelluma N, Tihan T, Vandenberg S, Tamgüney T, et al: Methylation of the PTEN promoter defines low-grade gliomas and secondary glioblastoma. Neuro-oncol 9: 271-279, 2007

195. Williams LT: Signal transduction by the platelet-derived growth factor receptor. Science 243:1564-1570, 1989

196. Wolf RM, Draghi N, Liang X, Dai C, Uhrbom L, Eklöf C, et al: p190RhoGAP can act to inhibit PDGF-induced gliomas in mice: a putative tumor suppressor encoded on human chromosome 19q13.3. Genes Dev 17:476-487, 2003

197. Wong KK, Chang YM, Tsang YT, Perlaky L, Su J, Adesina A, et al: Expression analysis of juvenile pilocytic astrocytomas by oligonucleotide microarray reveals two potential subgroups. Cancer Res 65:76-84, 2005

198. Wong KK, Tsang YT, Chang YM, Su J, Di Francesco AM, Meco D, et al: Genome-wide allelic imbalance analysis of pediatric gliomas by single nucleotide polymorphic allele array. Cancer Res 66:11172-11178, 2006

199. Yan H, Parsons DW, Jin G, McLendon R, Rasheed BA, Yuan W, et al: IDH1 and IDH2 mutations in gliomas. N Engl J Med 360:765-773, 2009

200. Yang B, Zhong C, Peng Y, Lai Z, Ding J: Molecular mechanisms of "off-on switch" of activities of human IDH1 by tumor-associated mutation R132H. Cell Res 20:1188-1200, 2010

201. Yin XL, Hui AB, Liong EC, Ding M, Chang AR, Ng HK: Genetic imbalances in pleomorphic xanthoastrocytoma detected by comparative genomic hybridization and literature review. Cancer Genet Cytogenet 132:14-19, 2002 


\section{Molecular biology of Grade II gliomas}

202. Yu J, Zhang H, Gu J, Lin S, Li J, Lu W, et al: Methylation profiles of thirty four promoter-CpG islands and concordant methylation behaviours of sixteen genes that may contribute to carcinogenesis of astrocytoma. BMC Cancer 4:65, 2004

203. Yu Y, Xu F, Peng H, Fang X, Zhao S, Li Y, et al: NOEY2 (ARHI), an imprinted putative tumor suppressor gene in ovarian and breast carcinomas. Proc Natl Acad Sci U S A 96:214-219, 1999

204. Zakrzewska M, Szybka M, Biernat W, Papierz T, Rieske P, Liberski PP, et al: Prevalence of mutated TP53 on cDNA (but not on DNA template) in pleomorphic xanthoastrocytoma with positive TP53 immunohistochemistry. Cancer Genet Cytogenet 193:93-97, 2009

205. Zhang JG, Kruse CA, Driggers L, Hoa N, Wisoff J, Allen JC, et al: Tumor antigen precursor protein profiles of adult and pediatric brain tumors identify potential targets for immunotherapy. $\mathbf{J}$ Neurooncol 88:65-76, 2008

206. Zhao S, Guan KL: IDH1 mutant structures reveal a mechanism of dominant inhibition. Cell Res 20:1279-1281, 2010
207. Zhao S, Lin Y, Xu W, Jiang W, Zha Z, Wang P, et al: Gliomaderived mutations in IDH1 dominantly inhibit IDH1 catalytic activity and induce HIF-1alpha. Science 324:261-265, 2009

208. Zhou Q, Anderson DJ: The bHLH transcription factors OLIG2 and OLIG1 couple neuronal and glial subtype specification. Cell 109:61-73, 2002

209. Zhu J, Zuo J, Xu Q, Wang X, Wang Z, Zhou D: Isocitrate dehydrogenase mutations may be a protective mechanism in glioma patients. Med Hypotheses 76:602-603, 2011

Manuscript submitted August 13, 2012.

Accepted December 6, 2012.

Please include this information when citing this paper: DOI: 10.3171/2012.12.FOCUS12283.

Address correspondence to: Nicholas F. Marko, M.D., The University of Texas MD Anderson Cancer Center, 1515 Holcombe Boulevard, FC7, Houston, Texas 77030. email: nfmarko@ mdanderson.org. 